\title{
AÇIK DENİZ RÜZGAR ENERJİSİ TÜRBİNLERİ TEKİL KAZIK TEMELLERİNİN ÇEVRESİNDEKİ BOŞLUK SUYU BASINCI GELIŞ̧ìi
}

\author{
H. Ercan TAŞAN ${ }^{1}$, Stavros A. SAVİDIS ${ }^{2}$, Cihan Taylan AKDAĞ $\breve{G}^{3}$ \\ ${ }^{1}$ Brandenburgische Technische Universität, Lehrstuhl Geotechnik, Senftenberg, COTTBUS \\ ${ }^{2}$ Technische Universität Berlin Fachgebiet Grundbau und Bodenmechanik-Degebo, BERLIN \\ ${ }^{3}$ Dokuz Eylül Üniversitesi, Torbalı Meslek Yüksekokulu, Geoteknik Programı, Torbalı, İZMİR

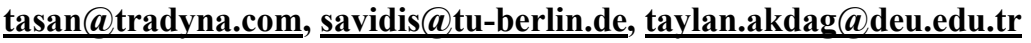

(Geliş/Received: 29.03.2012; Kabul/Accepted: 20.02.2014)

ÖZET

Açık deniz rüzgar türbin tasarımında yaygın olarak kullanılan geniş çaplı tekil kazıklar ağır rüzgar ve dalga yüküne maruz kalırlar. Söz konusu temel sistemlerinin davranışının incelenmesine ve güvenlikli tasarım yöntemlerinin geliştirilmesine ihtiyaç bulunmaktadır. Bu amaçla, geniş çaplı tekil kazık ile tasarlanan türbin temel sisteminin davranışı sonlu elemanlar yöntemi ile incelenmiştir. Zemin elemanları için iki fazlı ve üç boyutlu u20p8 olarak isimlendirilen sonlu elemanlar geliştirilmiştir. Böylelikle, nümerik analizler boyunca çalışma kapsamında odaklanılmış olan, kazığın çevresindeki zeminde boşluk suyu basıncı gelişiminin elde edilmesi mümkün olabilmiştir. Zemin hipoplastik malzeme modeli ile modellenmiştir. Analiz sonuçları, açık deniz yük koşullarında kazık çevresinde önemli derecede aşırı boşluk suyu basıncı gelişiminin kazık başı deplasmanlarını oldukça etkilediğini göstermiştir. Literatürde yer alan mevcut yöntemlerin geniş çaplı kazı̆̆ın deplasman tahmininde yetersiz kaldığı bulgulanmıştır. Sonrasında, kazık çapı-zemin geçirimliliğine dayanan parametrik analizler yapılmıştır. Analizler sonucu aşırı boşluk suyu basıncı birikim potansiyeline bağlı, temel tasarımında kullanılabilecek, karşılıklı etkileşim diyagramı sunulmuştur.

Anahtar kelimeler: Açık deniz rüzgar enerjisi türbinleri, tekil kazık temel, tekrarlı yük, hipoplastik malzeme modeli, iki fazlı model, nümerik analiz, aşırı boşluk suyu basıncı

\section{PORE WATER PRESSURE DEVELOPMENT AROUND THE MONOPILE FOUNDATIONS OF OFFSHORE WIND ENERGY CONVERTERS}

\begin{abstract}
Offshore wind energy converters (OWECs) require specific foundations due to special loading conditions. Large diameter monopiles are widely proposed for OWECs. The behavior of large diameter monopiles under cyclic lateral loads was investigated in this study by means of numerical simulation with finite element method. Special focus is given to the pore water pressure accumulation around the monopile. For this purpose a fully coupled two-phase finite element (u20p8) is developed. A hypoplastic constitutive model for the saturated sand soil is used in the numerical analyses. The results revealed that, pile head displacement is strongly dependent on excess pore water pressure (EPWP) accumulation around the monopile. Subsequently, pile diameter-hydraulic conductivity interaction diagram was derived with a parametric study to estimate the pore water pressure accumulation potential. The proposed interaction diagram enables a preliminary design tool of monopiles for offshore wind energy converters in saturated sand soils.
\end{abstract}

Keywords: Offshore wind energy converters, monopiles, cyclic loading, hypoplastic model, fully coupled twophase model, numerical analysis, excess pore water pressure 


\section{GIIRIŞ̧ (INTRODUCTION)}

Açık deniz rüzgar türbinleri oldukça yüksek bir enerji potansiyeline sahiptir. Bu nedenle, Avrupa'da son yıllarda yenilenebilir enerji kaynaklarının kullanımına yönelim önemli derecede artış göstermektedir. Örneğin Almanya'da, Kuzey Denizi ve Baltık Denizi'nde açık deniz rüzgar çiftliklerinin kurulmasına yönelik bir çok araştırma merkezi ve enstitüde geniş ölçekli araştırmalar yürütülmektedir [1].

Kıyıdan 20 ile $30 \mathrm{~km}$ uzaklıktaki mesafelerde, deniz taban derinliği $40 \mathrm{~m}$ ye ulaşan koşullar için planlanan rüzgar türbinleri çevresel koşullar nedeniyle ağır tekrarlı yüklere maruz kalmaktadır.

Tekil kazık temel sistemi açık deniz rüzgar türbinleri için yaygın olarak kullanılmakta olan uygun bir temel tipidir. Bu temellerin çapları dalga ve rüzgar yükleri gibi uzun dönemli tekrarlı yüklere karşı kazığın stabilitesini sağlamak amacıyla 7,0 $m$ ye kadar ulaşan geniş çaplarda tasarlanmaktadır.

Yapılan son araştırmalarda [2, 3, 4] tekil kazık temel tasarımında $p-y$ yönteminin kullanımı önerilmektedir. Ancak, doğrusal olmayan zemin direnci-kazık deformasyonu ilişkisine dayanan $p-y$ yöntemi, çapları $d<1,0 \mathrm{~m}$ ve tekrarlı yükleme sayısı $N \leq 100$ olan arazi kazık deneylerine dayanmaktadır $[5,6]$. Kazıkların boyutlandırılması için geliştirilen bir diğer yaklaşım, toplamda 34 kazık üzerinde uygulanmış tekrarlı yükleme sayısı ancak 500 e kadar ulaşan çeşitli deney sonuçlarına dayanmaktadır [7]. Açık deniz rüzgar türbinlerinin işletme ömrü 20 ile 25 yıl kadar olup bu süre içerisinde maruz kaldığ 1 tekrarlı yük sayısı $10^{9}$ a kadar ulaşabilmektedir. Ağır tekrarlı yükleme koşullarındaki bu türbinler için uygun olan geniş çaplı tekil kazıkların davranışının incelenmesinde yukarıda sözü edilen yöntemlerin uygunluğu henüz açıklık kazanmamıştır. Ayrıca [2, 7] tarafindan gerçekleştirilen çalışmalarda aşırı boşluk suyu basıncı gelişiminin tekil kazık deplasman davranışı ve taşıma kapasitesi üzerindeki etkisi ele alınmamıştır. $\mathrm{Bu}$ nedenle, mevcut çalışmada açık deniz koşullarında ağır tekrarlı yüklemeye bağlı olarak geniş çaplı kazığın çevresindeki zeminde meydana gelen aşırı boşluk suyu basıncı değişiminin belirlenmesine odaklanılmıştır. Çalışma, doğrusal olmayan nümerik analiz yöntemi ile gerçekleștirilmiștir. Farklı zemin sıkılıklarında ve farklı yükleme frekanslarında gerçekleştirilen analizler sonucu elde edilen boşluk suyu basıncı gelişimi etraflıca değerlendirilmiş̧ir. Analizler sonucu elde edilen tekrarlı yük-kazık başı deplasman ilişkisi önerilen mevcut yöntemlere $[2,7]$ dayanan sonuçlar ile karşılaştırılmıştır. Ayrıca zemin geçirimliliğinin aşırı boşluk suyu basıncı gelişimi üzerindeki etkisi incelenmiştir. Kazık çapı ve zemin geçirimliliğine bağlı parametrik analizler yapılarak aşırı boşluk suyu basıncı birikim potansiyeli belirlenmiş ve temel tasarımında kullanılabilecek karşılıklı etkileşim diyagramı sunulmuştur.

\section{YÖNTEM (METHOD)}

Nümerik analizlerde zemin malzeme özelliklerinin tanımlanmasında hipoplastik malzeme modeli kullanılmıştır. Hipoplastik malzeme modeli kohezyonsuz zeminler için uygun bir model olup [8, 9] toplamda sekiz parametre ile tanımlanır [10, 11, 12]. Tekrarlı yüklerin zemin davranışı üzerindeki etkisini inceleyebilmek amaciyla modele araştırmacılar tarafından eklemeler yapılarak model geliştirilmiştir [13]. Deformasyon yönünün zemin davranışı üzerindeki etkisi göz önüne alınarak danelerarası birim deformasyonunda ifade edildiği genişletilmiş model için modele beş parametre daha eklenmiştir [13].

Nümerik analizlerde zeminde aşırı boşluk suyu basıncı gelişiminin belirlenmesi amacıyla bu araştırma kapsamında iki fazlı model geliştirilmiştir. $\mathrm{Bu}$ model ile suya doygun zemin sonlu elemanlar modelinde tanımlanabilmiş ve analizlerde aşırı boşluk suyu basıncı gelişiminin elde edilmesi mümkün olabilmiştir. İki fazlı model, boşluklu ortam teorisine $[14,15]$ dayanmakta olup boşluk suyunun davranış üzerinde etkili olduğu geoteknik problemlerin tanımlanması açısından elverişli bir modeldir. İki fazlı modelde katı faz zemin danelerini, sıvı faz ise boşluk suyunu ifade etmektedir (Şekil 1-a). Bu çalışmaya özel olarak iki fazlı modele dayanan ve u20p8 olarak isimlendirilen üç boyutlu elemanlar geliştirilmiştir (Şekil 1-b). Deplasman tahmini 20 düğüm noktasından oluşan (u20) trikuadratik enterpolasyon fonksiyonlarıyla ve boşluk suyu basıncı tahmini 8 köşe düğüm noktasından oluşan (p8) trilineer enterpolasyon fonksiyonlarıyla gerçekleştirilmiştir.

İki fazlı modelin oluşturulmasında kullanılan temel denklemler kaynak [16] da ayrıntılı olarak açıklanmıştır. İki fazlı modelin doğrulaması amacıyla bir kil tabakasının konsolidasyonu [17] ve Hochstetten kumunun drenajsız koşullarda, tekrarlı yükler altında davranışının incelendiği [13] iki araştırma ele alınmıştır [16]. Söz konusu araştırmadaki zeminler u20p8 elemanları ile modellenerek iki fazlı modelin doğrulaması gerçekleştirilmiştir [16].

\subsection{Açık Deniz Tekil Kazık-Zemin Sisteminin Modellenmesi (Modelling of the Offshore Monopile Foundation System)}

Bu çalışmada, tekrarlı yüklemeye bağlı olarak kazığın çevresinde yer alan zeminde meydana gelen boşluk suyu basıncı birikiminin ve bu birikimin kazık davranışı üzerindeki etkisinin belirlenmesine odaklanılmıştır. $\mathrm{Bu}$ amaçla boyutları Şekil 2'de sunulan $5 M W$ kapasiteli bir açık deniz rüzgar türbini 
(a)

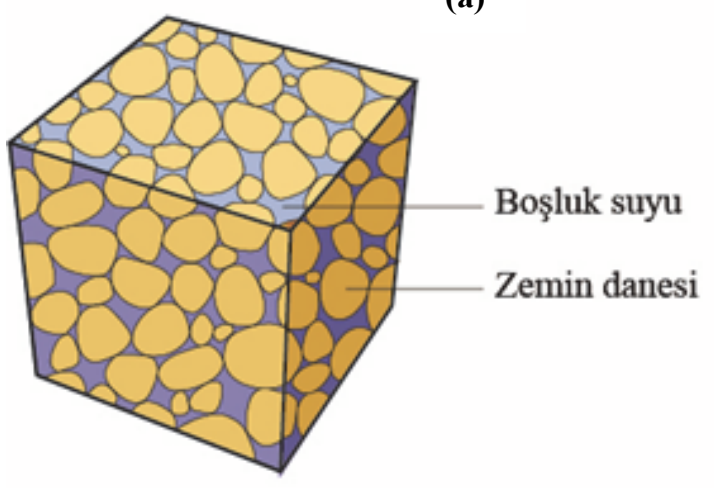

u20p8-Elemanı

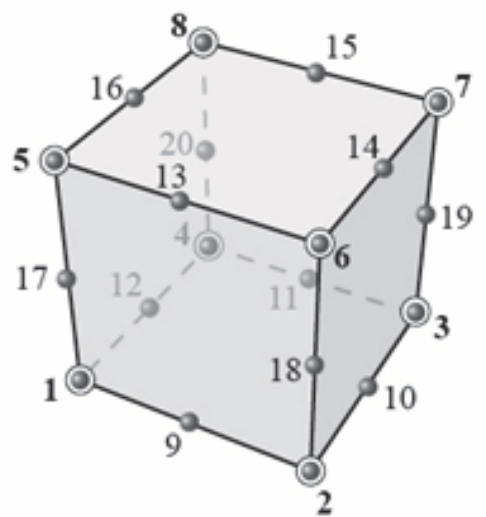

(b)

() $u_{x}, u_{y}, u_{z}$
() $u_{x}, u_{y}, u_{z}, p_{\mathrm{w}}$

Şekil 1. Zemin elemanı (a) iki fazlı model (b) üç boyutlu iki fazlı sonlu eleman modeli (Soil element (a) fully coupled two-phase model (b) 3-D two-phase FE)

için seçilen tekil kazık temel sisteminin üç boyutlu sonlu elemanlar modeli, sistemin eksenel simetrisi dikkate alınarak oluşturulmuştur (Şekil 3).

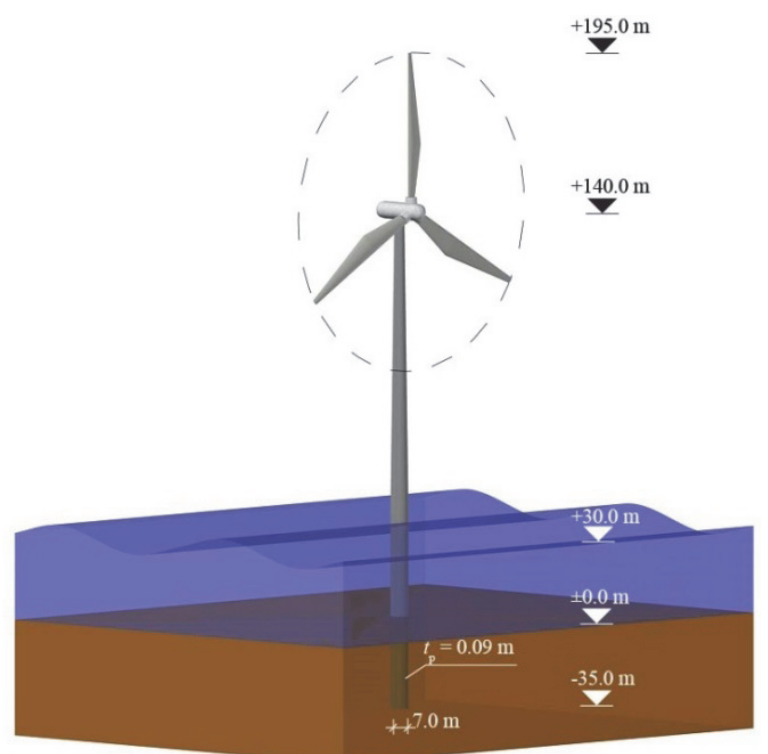

Şekil 2. Tekil kazıklı ve 5MW kapasiteli açık deniz rüzgar enerjisi türbini (Dimensions of a $5 \mathrm{MW}$ Offshore Wind Energy Converter with Monopile)

Model boyutları, kazığın yüklenmesi sonrası model sınırlarında herhangi bir etkilenmenin olmayacağ 1 şekilde yeterli büyüklükte tasarlanmıştır. Model boyutları Şekil 3 de kazık çapı, $d$ ye bağlı olarak gösterilmiştir. Zemin, kazığın çevresinde 7,5d genişliğinde dairesel olarak ve kazık tabanı altında 3,5d derinliğinde modellenmiştir. Sınır koşulları tanımlanırken model tabanı $x, y, z$, model simetri yüzeyi yüzeye dik $y$ ve model çevresi $x, y$ yönlerinde deplasmanlara kısıtlanmıştır. Zemin yüzeyi hariç bütün sınır yüzeyleri geçirimsiz olarak tanımlanmıştır.

Zemin modellemesi için Berlin kumu seçilmiştir. Berlin Teknik Üniversitesi Zemin Mekaniği
Laboratuvarı'nda gerçekleştirilen deneylerde kuru kumun minimum ve maksimum kuru birim hacim ağırlıkları sirasıyla: $\gamma_{d \min }=1,52 \mathrm{~g} / \mathrm{cm}^{3}, \gamma_{d \text { max }}=$ $1,88 \mathrm{~g} / \mathrm{cm}^{3}$, dane birim hacim ağırlığı: $\gamma_{s}=$ $2,66 \mathrm{~g} / \mathrm{cm}^{3}$ ve geçirimliliği: $\quad k_{d}=2$. $10^{-4} \mathrm{~m} / \mathrm{s}$ olarak belirlenmiştir.

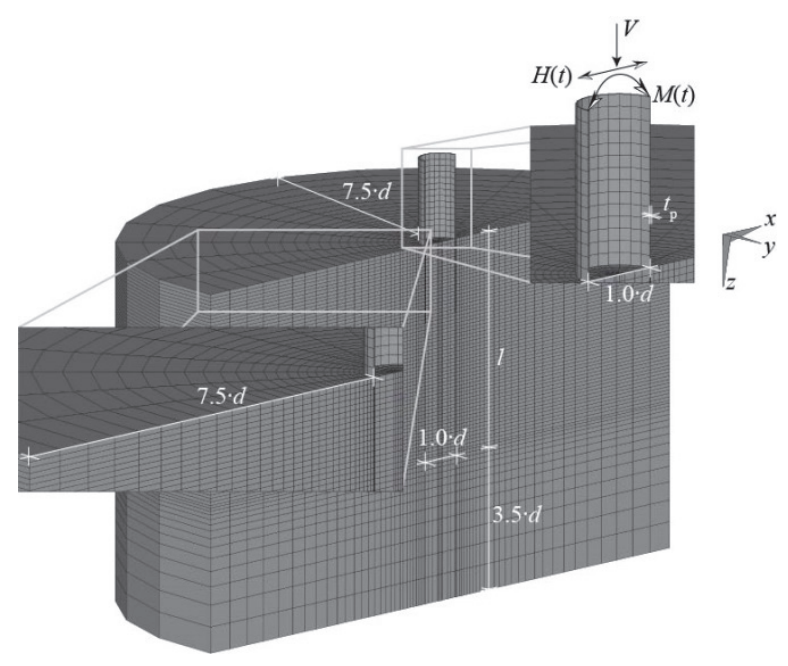

Şekil 3. Zemin-kazık sistemi sonlu elemanlar modeli (FEM of soil-monopile system)

Zemin hipoplastik malzeme modeli ile modellenmiştir. Kumun hipoplastik zemin parametreleri Tablol'de sunulmuştur. Hipoplastik malzeme modelinde kullanılan $\varphi_{\mathrm{c}}$ parametresi daneli zeminlerin en gevşek durumu için kritik içsel sürtünme açısını ifade etmektedir. Kullanılan parametreler arasında boyutlu tek değişken olan $h_{\mathrm{s} \text {, }}$ danelerin sıkışabilirliğini ifade eden bir rijitlik parametresidir. Danenin sertliğine, şekline ve dane çap1 dağılımına bağlı bir parametredir. Oransal sıkışma ifadesinde üstel bir parametre olan $n, h_{\mathrm{s}}$ parametresi ile doğrudan ilişkili olup dane büyüklüğü ve dane çapı dağılımına bağlıdır. Gerilmeye bağlı üç sınır boşluk oranı tanımlanmıştır: $e_{d 0}$, minimum boşluk oranını $e_{c 0}$, kritik boşluk oranını ve $e_{i 0}$, 
Tablo 1. Berlin Kumu özellikleri (Properties of Berlin Sand)

\begin{tabular}{c|c|c|c|c|c|c|c}
$\varphi_{\mathrm{c}}\left({ }^{\circ}\right)$ & $h_{\mathrm{s}}(\mathrm{MPa})$ & $n$ & $e_{d 0}$ & $e_{c 0}$ & $e_{\mathrm{i} 0}$ & $\alpha$ & $\beta$ \\
\hline 32,0 & 3730 & 0,20 & 0,41 & 0,74 & 0,89 & 0,14 & 1,0
\end{tabular}

\begin{tabular}{c|c|c|c|c}
$R$ & $m_{R}$ & $m_{T}$ & $\beta_{r}$ & $\chi$ \\
\hline $1 \cdot 10^{-4}$ & 5,0 & 2,0 & 0,4 & 6,0
\end{tabular}

maksimum boşluk oranını ifade etmektedir. Üstel bir parametre olan $\alpha$ daneli zeminlerdeki sıkılığın pik sürtünme açısı üzerindeki etkisini tanımlayan bir parametredir. Bir diğer üstel parametre olan $\beta$ sabit birim deformasyon ve sabit ortalama basınç durumunda sıkılığın artışıyla birlikte artan gerilme oranını ifade eden bir parametredir.

Tekrarlı yüklerin zemin davranışı üzerindeki etkisini inceleyebilmek amaciyla modele beş parametre daha ilave edilmiştir [13]. $\mathrm{Bu}$ parametrelerden $R$, danelerarası birim deformasyonu, $m_{R}$ ve $m_{T}$ rijitlik faktörlerini ifade etmektedir. $\beta_{r}$, danelerarası birim deformasyon gelişiminin etkisini ifade etmektedir. $\chi$, rijitliğin azalmasını ifade eden üstel bir parametredir.

Kazık elastisite modülü, $E=2,1 \cdot 10^{8} \mathrm{kN} / \mathrm{m}^{2}$ ve Poisson oranı, $v=0,3$ malzeme özelliklerinde modellenmiştir. Kazık, 20 düğüm noktasından oluşan sürekli elemanlar ve kazık-zemin yüzeyi surface-tosurface kontak elemanları ile tanımlanmıştır. Kontak elemanları sürtünme açısı $\delta=21^{\circ}$ olarak tanımlanmıştır.

Yükleme Kuzey Denizi'nde yapılmış ölçümler doğrultusunda DNV-Det Norske Veritas (2007) tarafından hazırlanmış “Açık Deniz Rüzgar Türbini Tasarımı" başlıklı offshore standardı dikkate alınarak uygulanmıştır. Ölçümler sonucu türbin merkezinin deniz taban seviyesinden $+140 m$ yükseklikte bulunduğu durum için 50 yıllık bir zaman diliminde bir kere gerçekleşmek üzere $60 \mathrm{~m} / \mathrm{s}$ hızla ve 3 saniye süreyle ağır rüzgar yükü tahmini yapılmıştır. Ek olarak, aynı zaman diliminde gerçekleşebilecek en fazla dalga yüksekliği $16 \mathrm{~m}$ olarak tahmin edilmiştir. Ölçümler sonucu yükleme frekansları $f<0,2 \mathrm{~Hz}$ olarak belirlenmiştir. Analizler, yukarıda ifade edilen ağır yük koşulları göz önüne alınarak sabit düşey

Tablo 2. Tasarım parametreleri (Design parameters) yük $V=12 M N$, tekrarlı yatay yük $H_{\max }=5 M N$ ve yatay yük dolayısıyla meydana gelen tekrarlı moment $M_{\max }=250 \mathrm{MNm}$ yükleme koşullarında gerçekleştirilmiştir (Tablo 2). Tablo 2'de $R$ ile tanımlanan tekrarlı yükleme karakteristiği ayrıntıları Şekil 4 de sunulmuştur. Analizlerde başlangıç adımında yerçekimi kuvveti ve geostatik yanal zemin basınc $K_{o}$ kullanılarak zeminde geostatik gerilme durumu elde edilmiştir. Geostatik durumun tanımlanmasının ardından tekrarlı yükleme adımı uygulanmıștır.

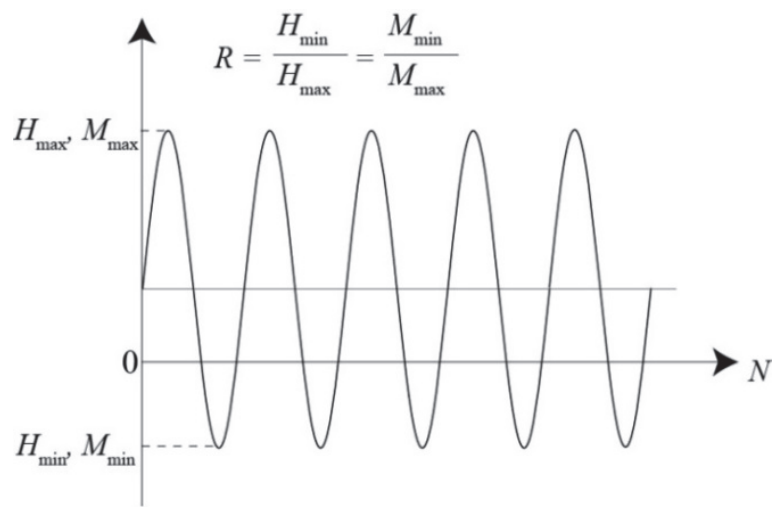

Şekil 4. Tekrarlı yük karakteristiği, $R$ (Characteristic of cyclic loading, $R$ )

\section{ANALIZ BULGULARI (ANALYSIS RESULTS)}

\subsection{Aşırı Boşluk Suyu Basıncı Gelişimi (Excess Pore Water Pressure (EPWP) Development)}

Zemin sıkılığının, ağır yükleme koşullarının ve sinüzoidal yükleme frekansının boşluk suyu basıncı gelişimi üzerindeki etkisini incelemek amacıyla gevşek ve çok sıkı kum koşullarında farklı frekanslarda toplam üç analiz gerçekleştirilmiştir (Tablo 3).

\begin{tabular}{|c|c|c||c|c|c|c|c||}
\hline \multicolumn{3}{|c||}{ KazıkBoyutları } & \multicolumn{4}{c||}{ Yükleme Koşullar1 } & Su Derinliği \\
\hline \hline $\begin{array}{c}d \\
(\mathrm{~m})\end{array}$ & $\begin{array}{c}l \\
(\mathrm{~m})\end{array}$ & $\begin{array}{c}t \\
(\mathrm{~m})\end{array}$ & $\begin{array}{c}H_{\max } \\
(\mathrm{MN})\end{array}$ & $\begin{array}{c}M_{\max } \\
(\mathrm{MNm})\end{array}$ & $\begin{array}{c}V \\
(\mathrm{MN})\end{array}$ & $R$ & $\begin{array}{c}h \\
(m)\end{array}$ \\
\hline 7 & 35 & 0,09 & 5 & 250 & 12 & 0 & 35 \\
\hline
\end{tabular}


Tablo 3. Zemin Sıkılığı ve yükleme frekansı (Relative density and loading frequency)

\begin{tabular}{|c|c|c|}
\hline \multicolumn{3}{|c|}{ Yatay yük } \\
\hline \hline Analiz & Sik1lık durumu, $D_{r}(\%)$ & Yükleme frekans1, $f(\mathrm{~Hz})$ \\
\hline I & 32 & 0,16 \\
\hline II & 92 & 0,16 \\
\hline III & 92 & 0,06 \\
\hline
\end{tabular}

Analizler sonucu elde edilen aşırı boşluk suyu basıncı oluşum konturları belirli yük tekrarları için Şekil 5, Şekil 7 ve Şekil 9 da sunulmuştur. Her bir analiz sonucu elde edilen tekrarlı yük-kazık başı deplasman birikim ilişkisi literatürde önerilen mevcut yöntemler $[2, \quad 7]$ kullanılarak elde edilen sonuçlar ile karşılaştırılmıştır (Şekil 6, Şekil 8, Şekil 10). Analizlerde tekrarlı yüklemenin başlangıç yönü şekillerden de görüleceği üzere $+\boldsymbol{x}$ yönünde uygulanmıştır.

Tüm analiz sonuçları göstermektedir ki ağır tekrarlı yük nedeniyle kazığın çevresindeki zeminde kama biçiminde aşırı boşluk suyu basıncı gelişmektedir. Ayrıca, tüm analiz sonuçlarında yükleme tekrar sayısı $N=1,5$ a kadar, ilk yükleme yönünün tersi yönünde kazığın çevresindeki zeminde negatif boşluk suyu basıncı oluşmuştur. Yük tekrar sayısı arttıkça kazığın her iki yönünde bulunan zeminde pozitif aşırı boşluk suyu basıncı gerçekleşmiştir. Ek olarak, tekrar sayısı arttıkça aşırı boşluk suyu basıncı oluşum bölgesi genişlemiş ve derinleşmiştir. Dikkat edilmelidir ki başlangıç tekrarlarından itibaren kazık yüzeyine en yakın bölgede bulunan zeminde aşırı boşluk suyu basınc1 artımı o bölgedeki zeminde önemli derecede dayanım ve rijitlik kaybının gerçekleştiğini göstermektedir.

Analiz I (gevşek kum) ve Analiz II (çok sıkı kum) de yükleme aynı frekansta $f=0,16 \mathrm{~Hz}$ uygulanmıştır. Gevşek kumda aşırı boşluk suyu basıncı oluşum kaması sıkı kum koşulunda elde edilene göre çok daha hızlı bir şeklide genişlemiştir. Gevşek kum koşulunda henüz $N=1,5$ tekrarında aşırı boşluk suyu basıncı kazık tabanına ulaşmış ve kazığın içine doğru ilerlemiştir. Ayrıca geniş bir bölgede aşırı boşluk suyu basıncı gelişimi nedeniyle zemin önemli ölçüde dayanımını ve rijitliğini kaybetmiştir. Buna rağmen çok sıkı zemin koşulunda (Analiz II) benzer olay daha ilerideki tekrar sayısında $N=$ 7,5 gerçekleşmiştir.

Analiz II ve Analiz III, aynı sıkılıkta zemin koşulunda ve iki ayrı frekansda uygulanmıştır. Analizlerde tekrar sayısına bağlı olarak benzer aşırı boşluk suyu basıncı gelişimi gözlemlenmekle birlikte Analiz II ( $f=$ $0,16 \mathrm{~Hz})$ de $N=7,5$ tekrarında aşırı boşluk suyu basıncı kazığın içine doğru tamamen yayılmış iken Analiz III $(f=0,06 \mathrm{~Hz})$ de $N=7,5$ tekrarında aşırı boşluk suyu basıncı kazık tabanına henüz ulaşmaktadır.

Analiz I, II ve III de elde edilen tekrarlı yüke bağlı kazık bașı deplasman birikimlerinin mevcut yöntemler [2, 7] ile elde edilenlerden özellikle ilk iki tekrardan sonra önemli derecede farklı ve yüksek olduğu bulgulanmıştır. (Şekil 6, Şekil 8, Şekil 10).

Ağır tekrarlı yük koşullarının aşırı boşluk suyu basıncı davranışı üzerindeki etkisinin boyutlarını açığa çıkarmak amacıyla Analiz III ile aynı kazık, zemin ve yükleme frekansı özelliklerine sahip ancak düşük yükleme koşulunda $\left(H=0,1 \cdot H_{\max }\right.$ ve $\left.M=0,1 \cdot M_{\max }\right)$ bir analiz daha gerçekleştirilmiştir. Analiz sonucu tekrarlı yüklemenin hemen başlangıcında $(N=0,5)$ ve tekrarın artışıyla $(N=11,5)$ kazık yüzeyine yakın zemin bölgesinde oldukça düşük aşırı boşluk suyu basıncı gelişimi elde edilmiştir. (Şekil 11).

Düşük yükleme koşullarında yapılan nümerik analiz sonucu elde edilen tekrarlı yük-kazık başı deplasman birikimi sonuçları ile mevcut yöntemler [2, 7] kullanılarak elde edilen sonuçlar benzer davranış göstermiştir (Şekil 12). 

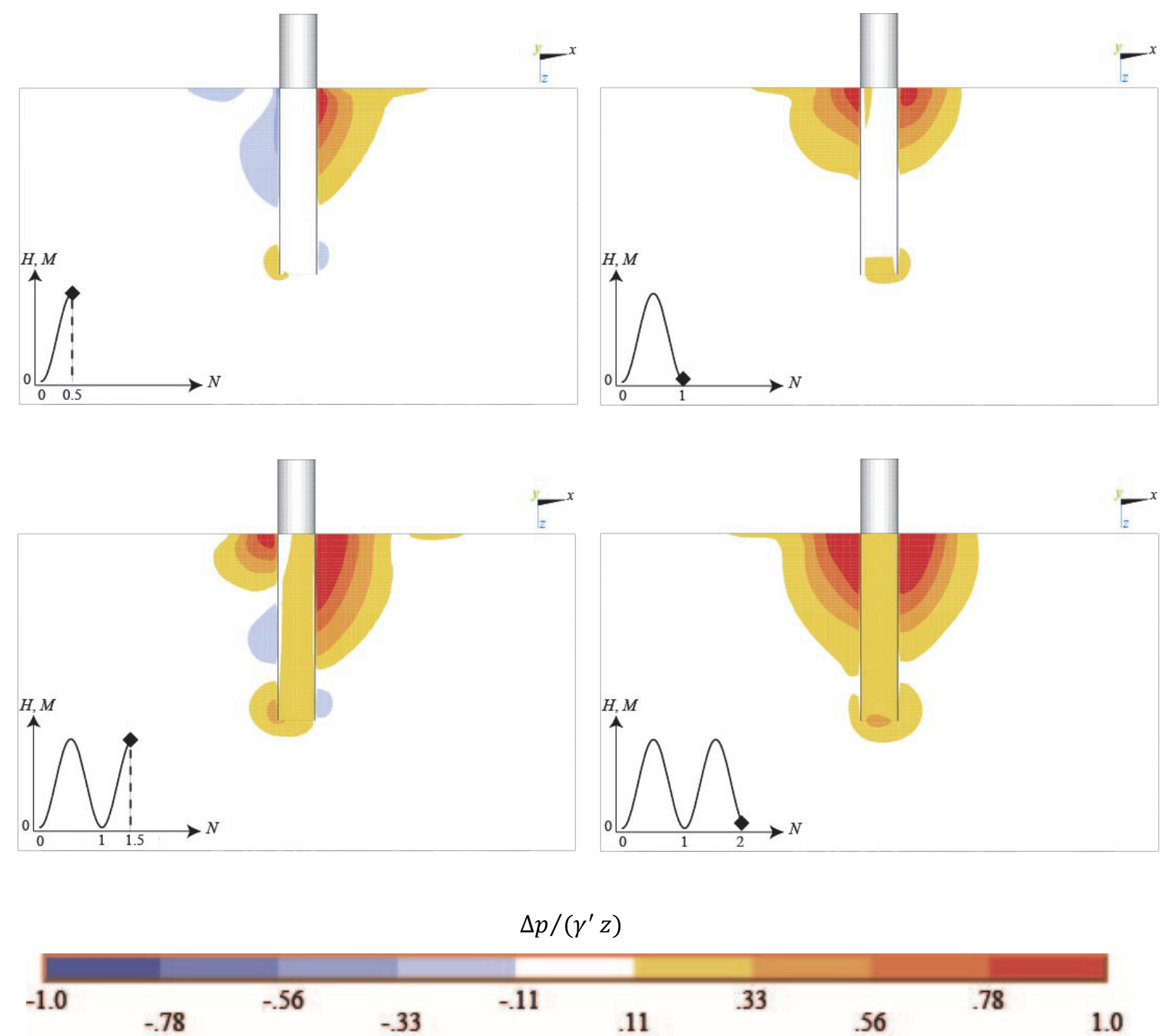

Şekil 5. Analiz I: Tekrar sayısına bağlı aşırı boşluk suyu basıncı gelişimi, $f=0,16 \mathrm{~Hz}$ (Analyze I: Contours of excess pore water pressure accumulation in loose sand, $f=0,16 \mathrm{~Hz}$ )

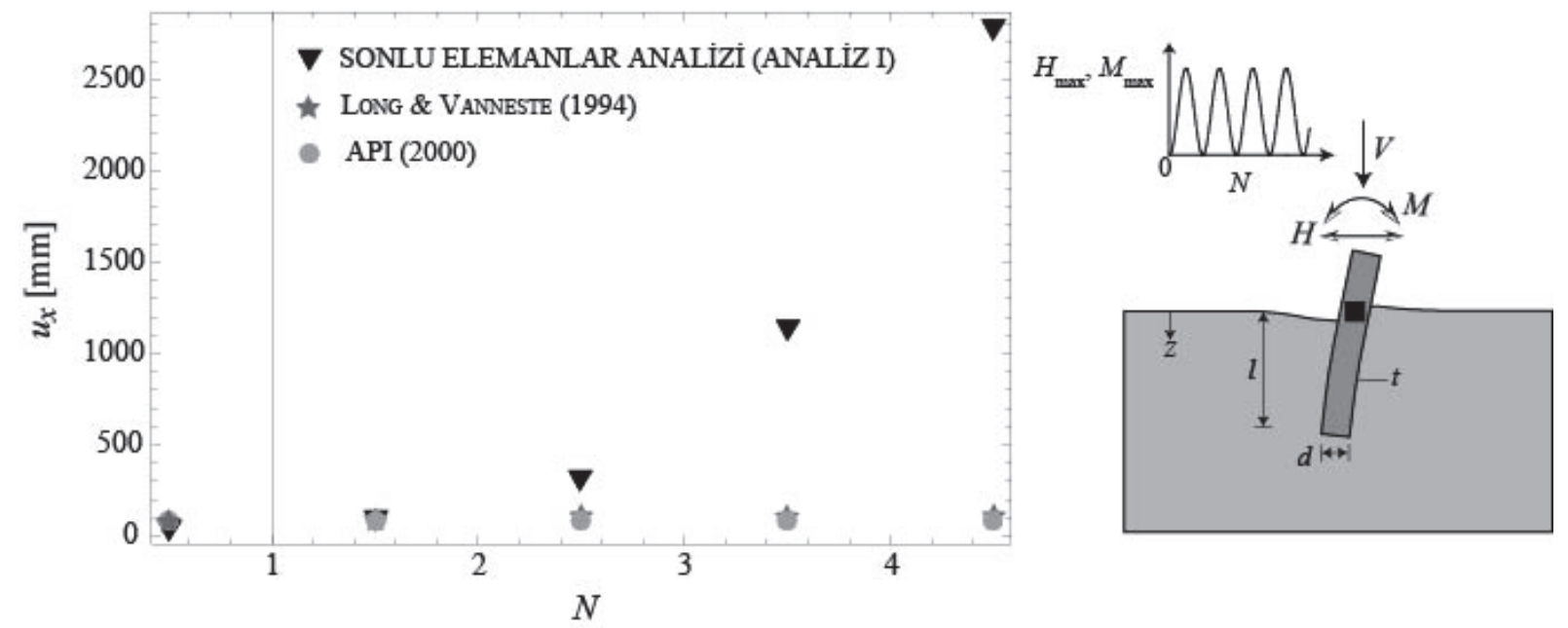

Şekil 6. Gevşek kumda yük tekrar sayısı-kazık başı deplasman ilişkisi, $f=0,16 \mathrm{~Hz}$ (Load-head displacement relationships in loose sand, $f=0,16 \mathrm{~Hz}$ ) 

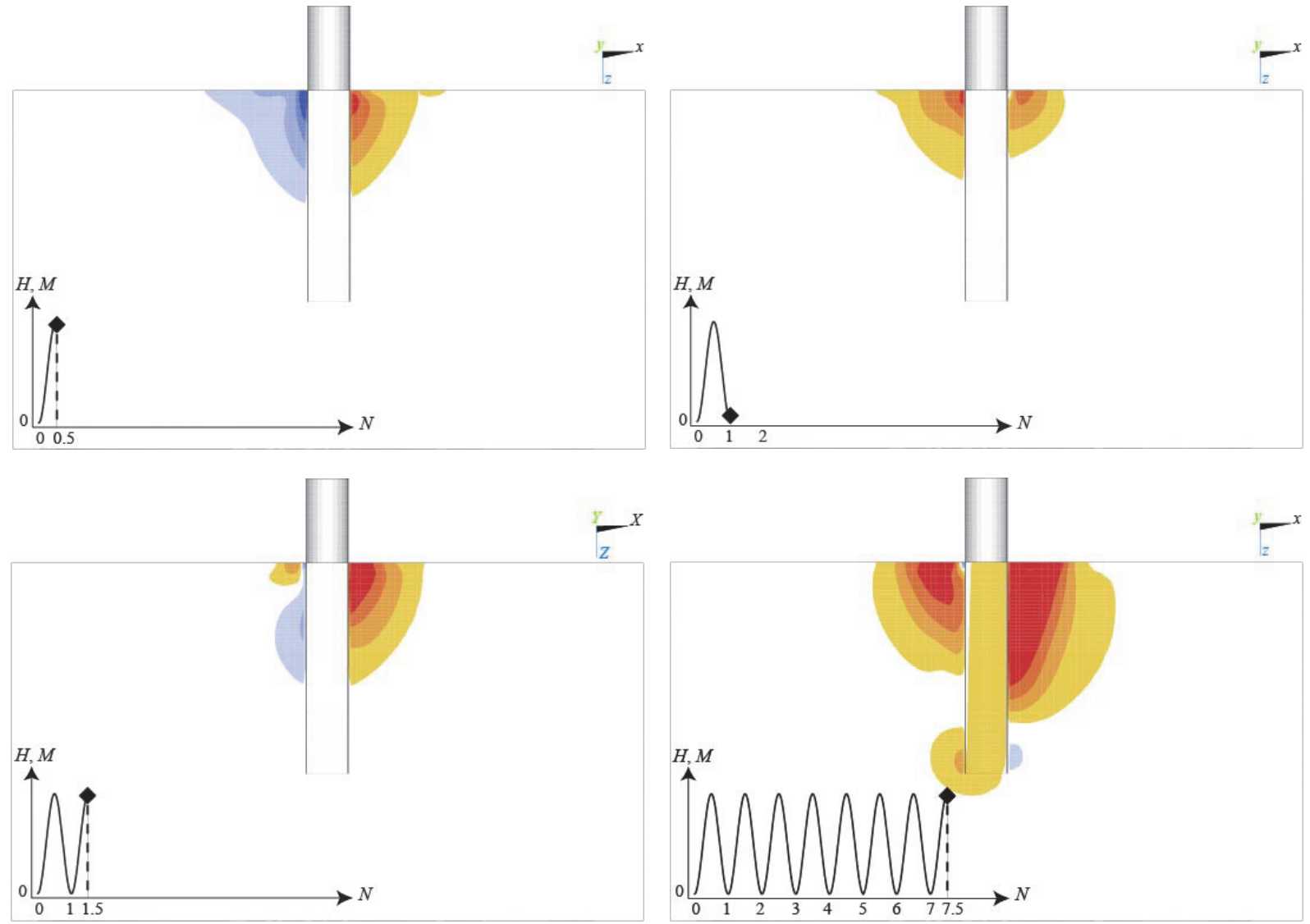

$\Delta p /\left(\gamma^{\prime} z\right)$

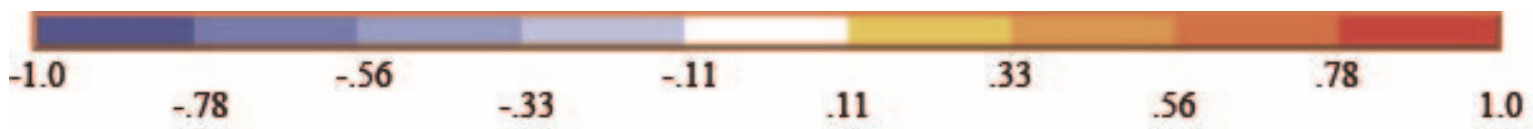

Şekil 7. Analiz II: Tekrar sayısına bağlı aşırı boşluk suyu basıncı gelişimi, $f=0,16 \mathrm{~Hz}$ (Analyze II: Contours of excess pore water pressure accumulation in dense sand, $f=0,16 \mathrm{~Hz}$ )

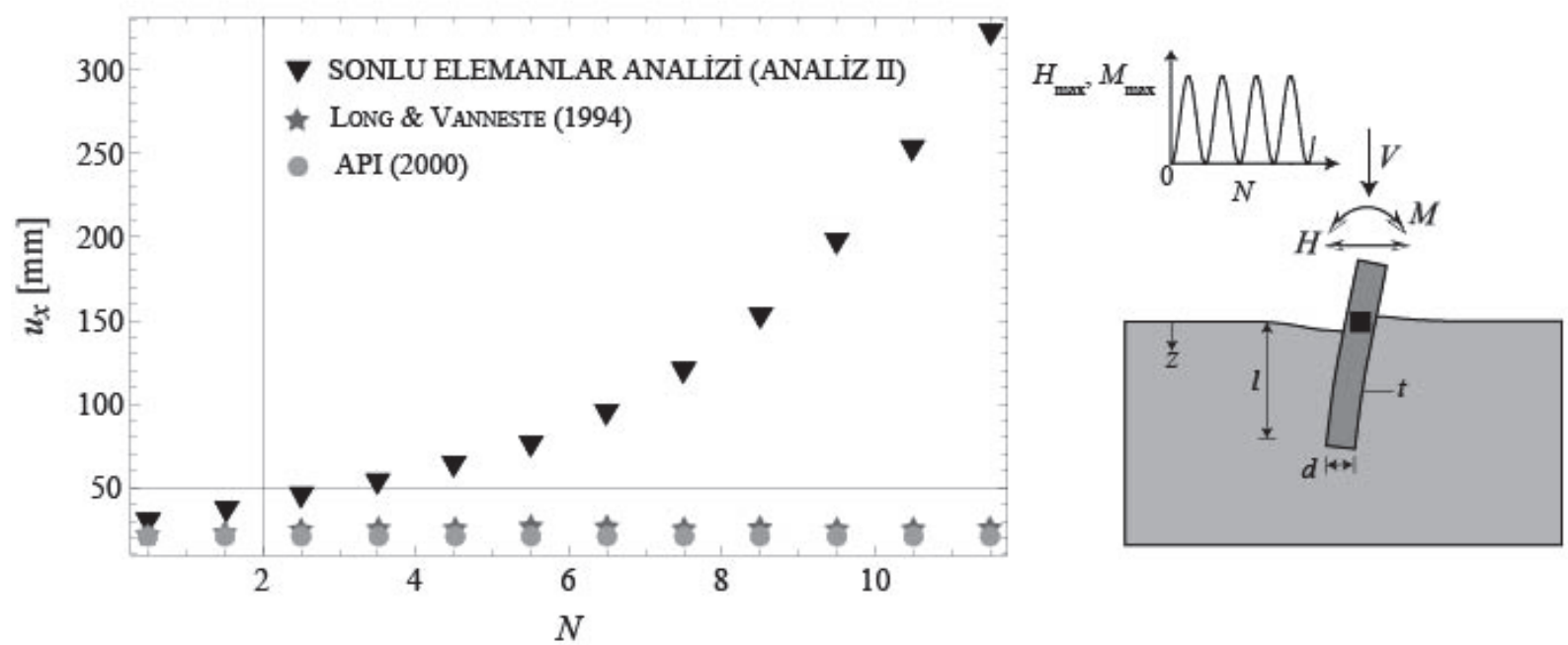

Şekil 8. Çok sıkı kumda yük tekrar sayısı-kazık başı deplasman ilişkisi, $f=0,16 \mathrm{~Hz}$ (Load-head displacement relationships in very dense sand, $f=0,16 \mathrm{~Hz}$ ) 

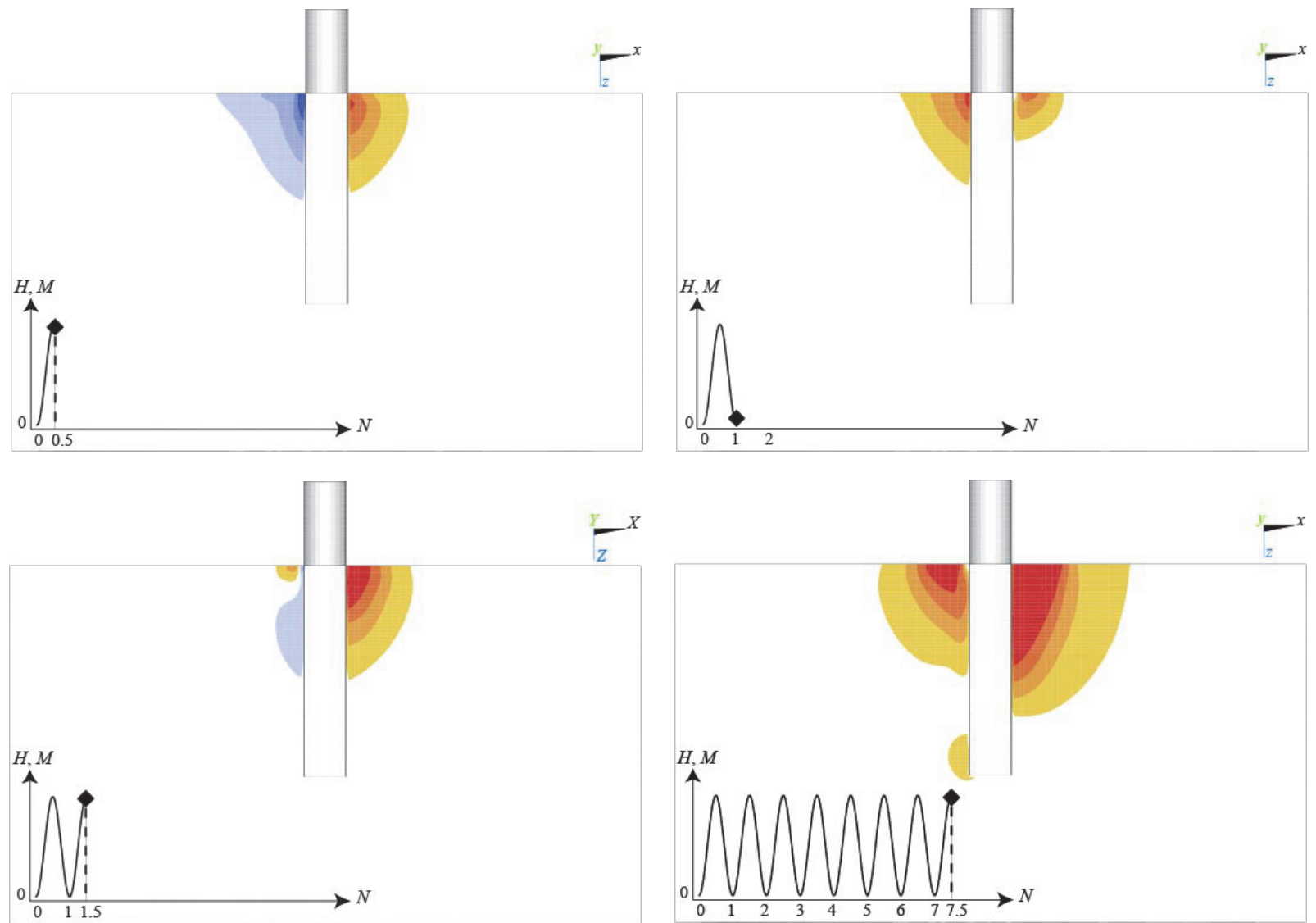

$\Delta p /\left(\gamma^{\prime} z\right)$

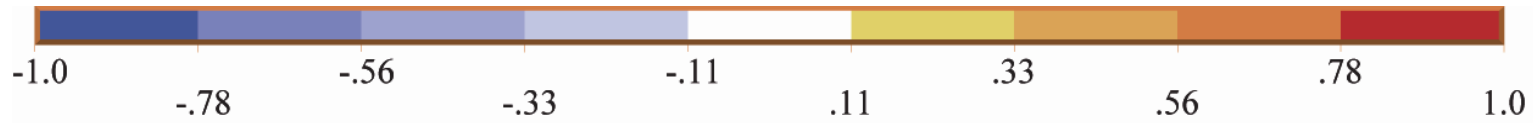

Şekil 9. Analiz III: Tekrar sayısına bağlı aşırı boşluk suyu basıncı gelişimi, $f=0,06 \mathrm{~Hz}$ (Analyze III: Contours of excess pore water pressure accumulation in dense sand, $f=0,06 \mathrm{~Hz}$ )

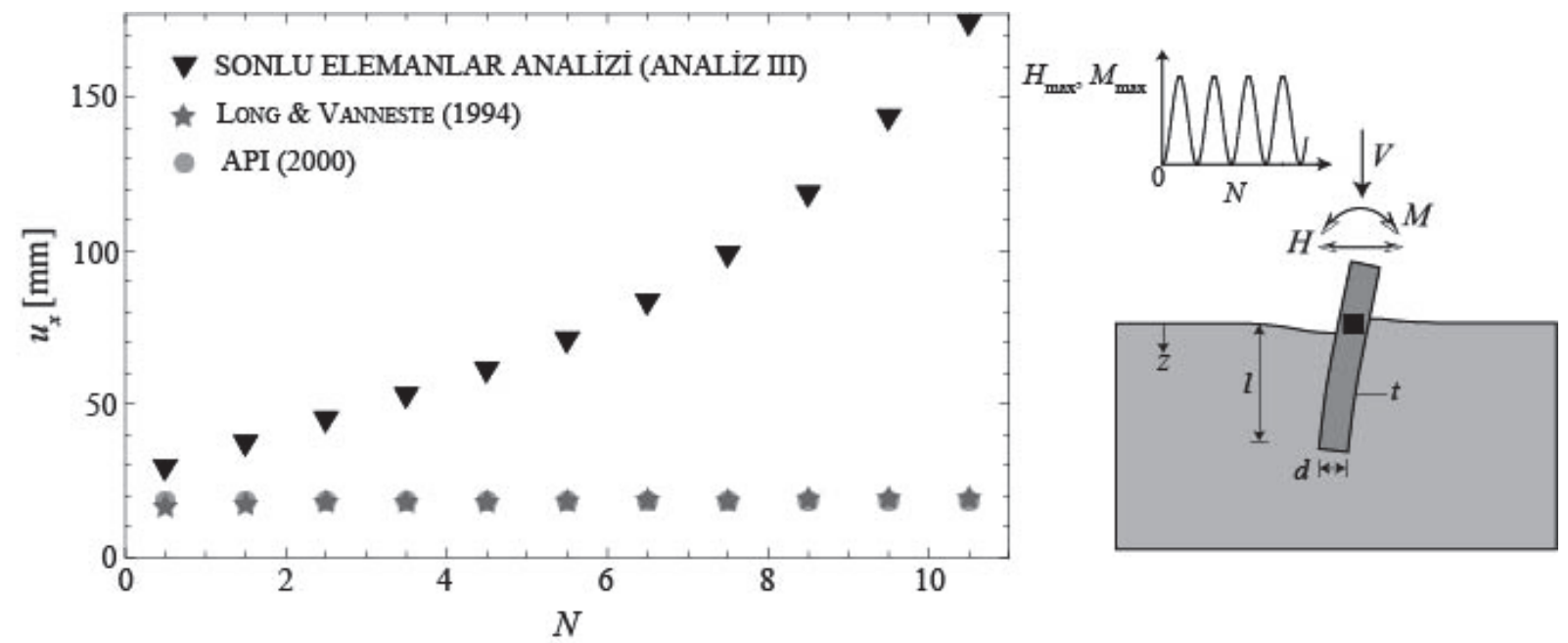

Şekil 10. Çok sıkı kumda yük tekrar sayısı-kazık başı deplasman ilişkisi, $f=0,06 \mathrm{~Hz}$ (Load-head displacement relationships in very dense sand, $f=0,06 \mathrm{~Hz}$ ) 


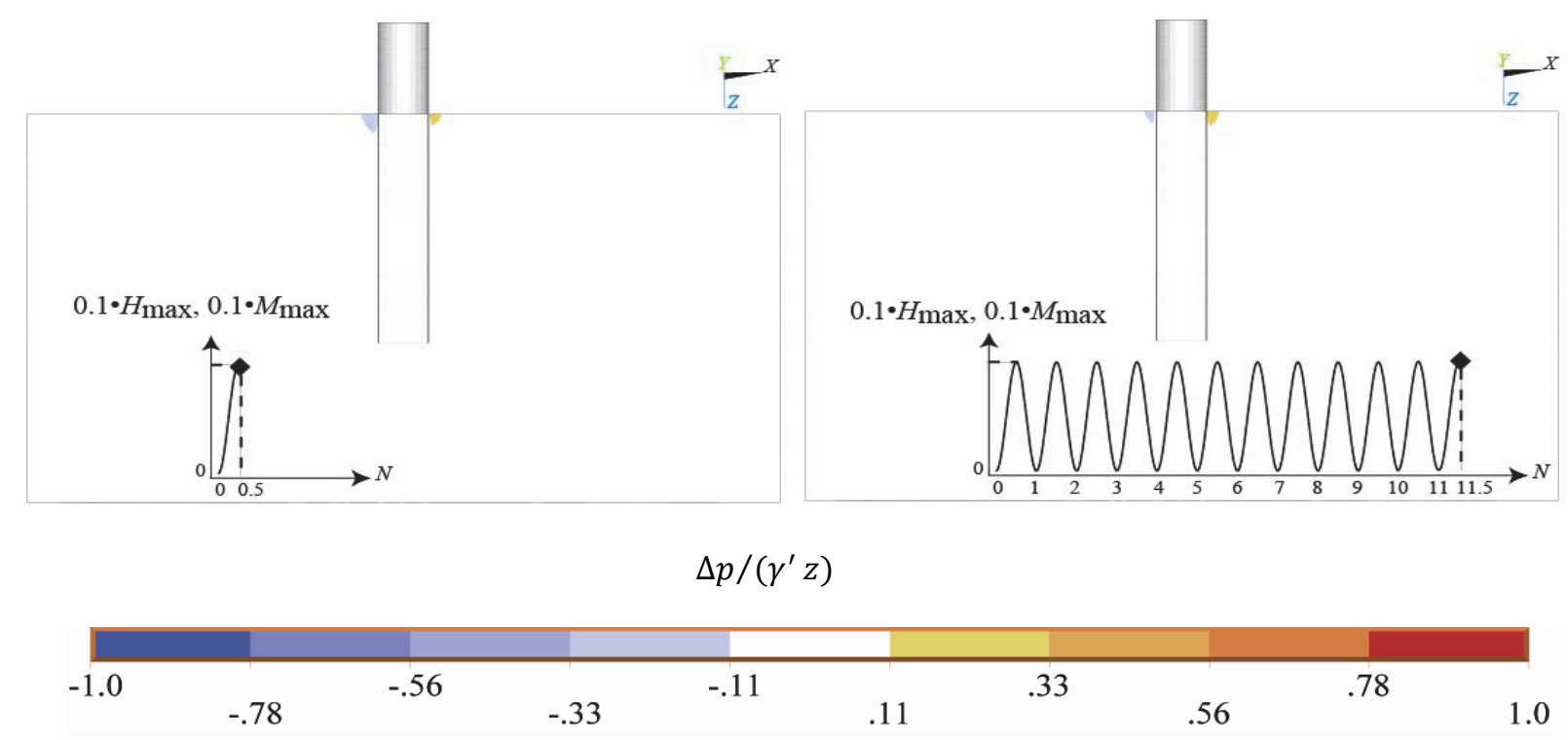

Şekil 11. Düşük yükleme koşulunda aşırı boşluk suyu basıncı gelişimi, $f=0,06 \mathrm{~Hz}$ (Contours of excess pore water pressure accumulation in very dense sand and low loading conditions, $f=0,06 \mathrm{~Hz}$ )

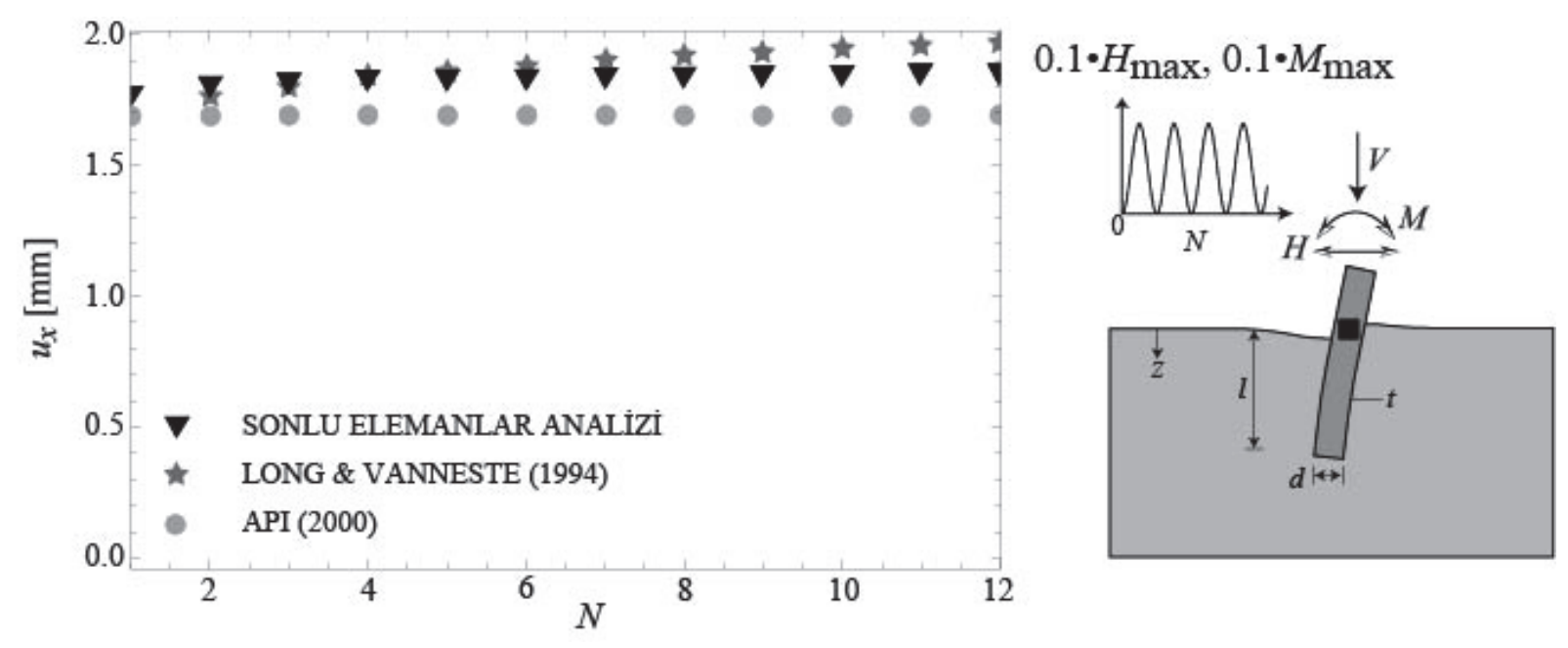

Şekil 12. Düşük yükleme koşullarında yük tekrar sayısı-kazık başı deplasman ilişkisi, $f=0,06 \mathrm{~Hz}$ (Load-head displacement relationship under low loading conditions, $f=0,06 \mathrm{~Hz}$ )

\subsection{Aşırı Boşluk Suyu Basıncı Oluşum Potansiyelinin Belirlenmesi (Prediction of Excess Pore Water Pressure Accumulation Potential)}

Çalışmanın bu bölümünde kazık çapı ve zemin geçirimliliğinin aşırı boşluk suyu basıncı davranışı üzerindeki etkisi incelenmiştir. Parametrik çalışma için sıkı kum $D_{r}=0,83$ koşullarında hipoplastik zemin parametreleri Tablo 1'de sunulan Berlin kumu kullanılmıștır. Analizlerde yükleme deplasman kontrollü olarak gerçekleştirilmiş olup bir tekrar boyunca oluşan davranış incelenmiştir. Yükleme, tekrarının yarısı esnasında deplasman değeri kazık çapının onda birine $(w=d / 10)$ karşılık gelecek ve birinci tekrarın sonunda deplasman başlangıç noktasına dönecek şekilde, $f=0,06 \mathrm{~Hz}$ frekansında gerçekleştirilmiştir. Analizler, kazık çapı $d=8 \mathrm{~m}$ olan tekil kazık sistemi üzerinde iki farklı geçirimlilik değerinde (Analiz-a ve Analiz-b) gerçekleştirilmiştir. Kazık boyunca elde edilen boyutsuz derinlik-boyutsuz aşırı boşluk suyu basıncı ilişkisi Şekil 13'de sunulmuştur. Geçirimliliği $k_{d}=1 \cdot 10^{-4} \mathrm{~m} / \mathrm{s}$ olan zemin durumunda yüklemenin hemen başlangıç anında $(t / T=0,03)$ aşırı boşluk suyu basıncı kazık boyunca gerçekleşmiştir. Dikkat edilmelidir ki boşluk suyu basıncı kazığın dönme derinliğine kadar pozitif, dönme derinliğinin altında beklendiği üzere negatif olarak gerçekleşmiştir. Geçirimliliği 400 kat daha fazla olan, $k_{d}=400 \cdot 10^{-4} \mathrm{~m} / \mathrm{s}$ zemin durumunda ise kazık derinliğinin iki katına kadar $(z / d=2)$ olan derinliğin altında neredeyse aşırı boşluk suyu basıncı oluşmamış, üstünde ise Analiz- $a$ ile karşılaştırıldığında oldukça düşük seviyede gerçekleşmiştir. Analiz- $a$ da $t / T=0,5$ anında özellikle $z / d$ derinliği 1,0 ve 2,5 arasında boyutsuz aşırı boşluk suyu basıncı, $\Delta p /\left(\gamma^{\prime} z\right)$, dlşbükey bir 


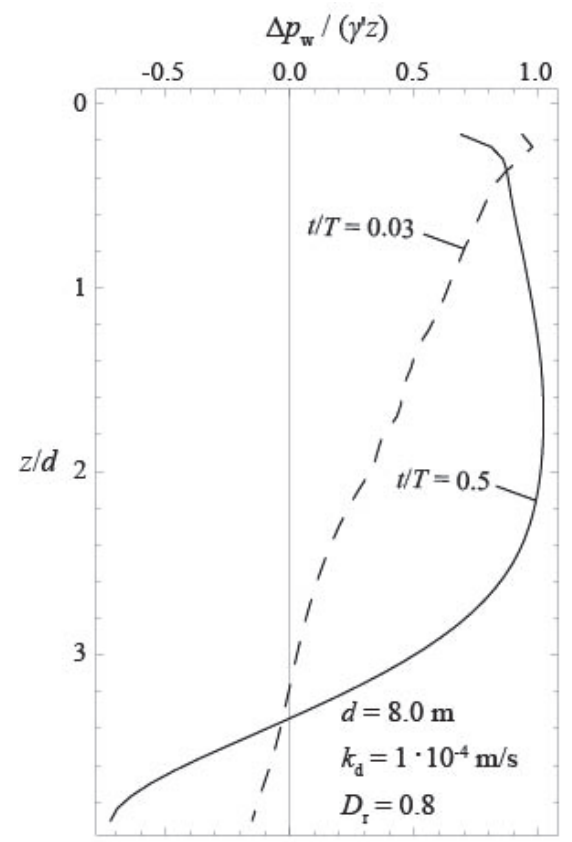

a)

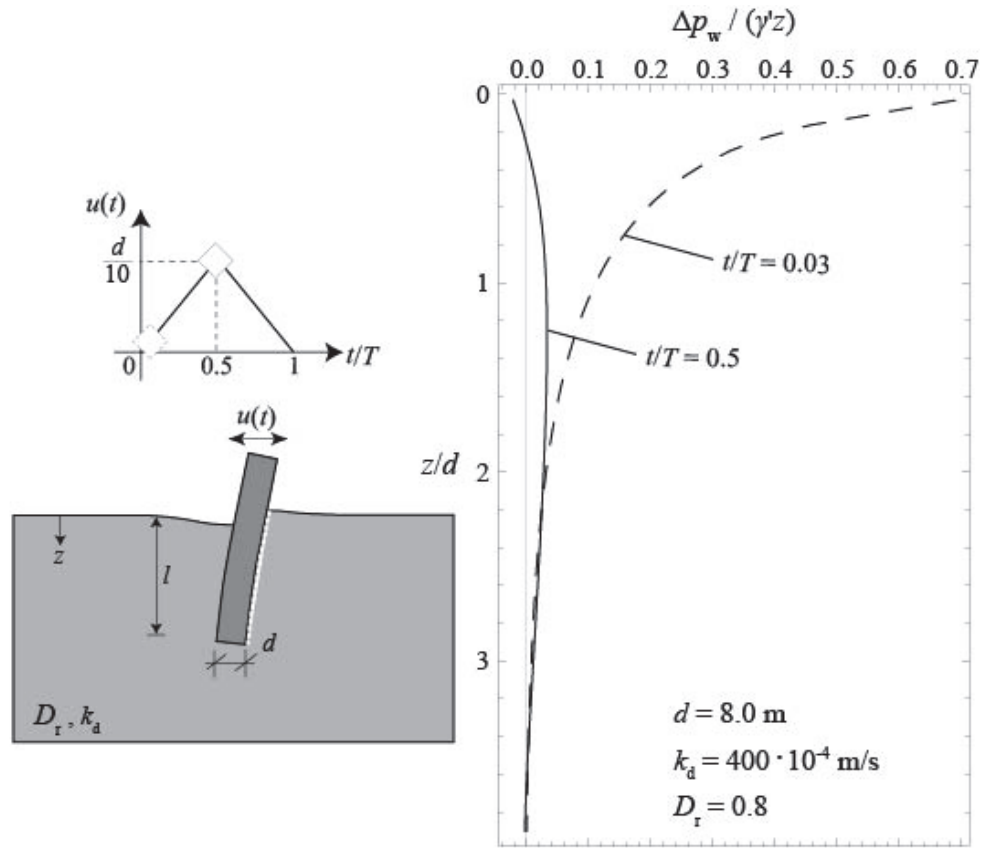

b)

Şekil 13. Kazık derinliği boyunca aşırı boşluk suyu basıncı (a) Analiz-a: Geçirimliliği düşük zemin (b) Analiz-b: Geçirimliliği yüksek zemin (Excess pore water pressure distribution along the pile depth (a) Analysis- $a$ : Low permeabity condition (a) Analysis- $b$ : High permeabity condition)

şekil oluşturmuş olup 0,90 değerinin üzerinde gerçekleşmiştir. Bir başka ifade ile bu bölgede zemin dayanım ve rijitliği önemli derecede azalmıştır (Şekil 13 a). Bunun yanı sira Analiz-a da deplasman artımı ile aşırı boşluk suyu basıncı önemli derecede artmıştır. Buna karşılık Analiz-b de geçirimliliğin yüksek olması nedeniyle deplasman arttıkça (örneğin $t / T=0,5$ anında) kazık boyunca aşırı boşluk suyu basıncı elimine olmuştur (Şekil 13 b).

Analiz-a ve Analiz-b sonuçları geçirimliliğin kazık boyunca aşırı boşluk suyu basıncı davranışını önemli derecede etkilediğini göstermiştir. $\mathrm{Bu}$ anlamda aşırı boşluk suyu basıncı oluşum potansiyelini belirleyebilmek amacıyla farklı kazık çapı ve farklı geçirimlilik kombinasyonlarında parametrik analiz gerçekleştirilmiştir. Parametrik çalışmada Analiz- $a$ ve Analiz- $b$ de uygulanan tekrarlı yükleme yöntemi kullanılmıştır. Analizler sonucu $t / T=0,03$ ve $t / T=0,5$ anlarındaki aşırı boşluk suyu basıncı oluşumunun kazık başından $z / d=2$ derinliğine kadar olan kısmı değerlendirilmiştir. Basıncın $t / T=$ 0.5 anında $t / T=0,03$ anına göre elimine olduğu durumlar aşırı boşluk suyu basıncı birikiminin gerçekleşmediği, artan durumlar ise aşırı boşluk suyu basıncı birikiminin gerçekleştiği durumlar olarak değerlendirilmiştir (Şekil 14). Analiz verileri açık deniz rüzgar enerjisi türbinleri tekil temel sistemlerinin tasarımında aşırı boşluk suyu basıncı gelişiminin kaçınılmaz bir şekilde dikkate alınması gerektiğini ifade etmektedir.

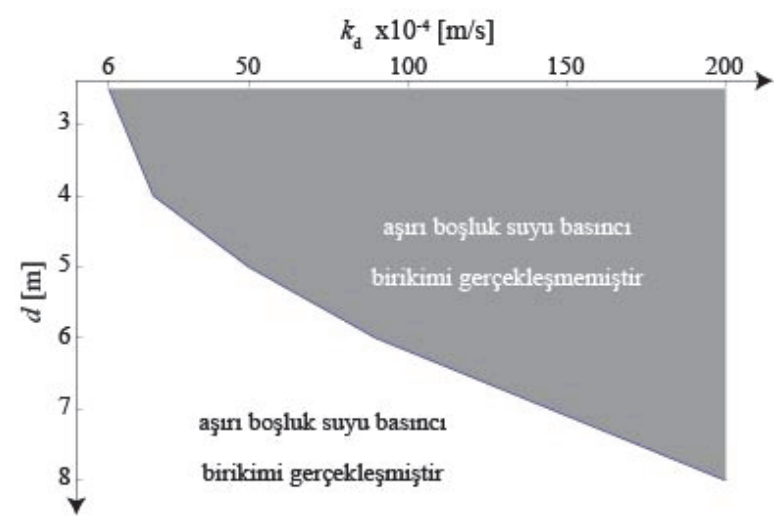

Şekil 14. Zemin-tekil kazık sisteminde aşırı boşluk suyu basincı oluşum potansiyeli (Excess pore water pressure accumulation potential in soil-monopile systems)

\section{SONUÇLAR (CONCLUSIONS)}

Açık deniz ağır yük koşullarında tekrarlı yükleme sonucu 7,0 m çaplı kazığın yakın çevresindeki zeminde dayanım ve rijitlik kaybı sadece gevşek zemin durumunda değil aynı zamanda çok sıkı zemin koşullarında da oluşmuştur. Buna karşın on katı kadar düşük tekrarlı yükleme koşullarında kazığın çevresinde oldukça düşük boşluk suyu basıncı oluşumu gerçekleşmiş ve dayanım kaybı gözlemlenmemiştir.

Tekrarlı yük-kazık başı deplasman eğrileri göstermektedir ki düşük yükleme koşullarında mevcut 
yöntemlerle elde edilen sonuçlar ile analiz sonuçları arasında önemli bir fark oluşmamaktadır. Buna karşılık açık deniz koşullarındaki yüklemeler dikkate alınarak yapılan analiz sonucu elde edilen kazık başı deplasmanları mevcut yöntemler kullanılarak elde edilen deplasmanlardan önemli derecede farklılık göstermiştir. Aşırı boşluk suyu basıncı gelişimi kazık başı deplasmanını dikkate değer biçimde arttırmıştır. Mevcut yöntemler açık deniz koşullarındaki ağır yüklerin neden olduğu aşırı boşluk suyu basıncı gelişimini dikkate almadığından kazık başı deplasman tahmininde yetersiz kalmaktadır.

Analiz sonuçları göstermektedir ki tekrarlı ağır yatay yük koşullarında ve çok sıkı zemin durumunda yükleme frekansı artışı daha hızlı bir boşluk suyu basıncı artışına ve yayılımına neden olmaktadır.

Farklı kazık çapı ve farklı geçirimlilik kombinasyonlarında aşırı boşluk suyu basıncı oluşum potansiyelini tahmin etmek için yapılan parametrik analiz sonuçlarına göre geniş çaplı, özellikle 7-8 m çaplı tekil kazıklarda hemen hemen tüm geçirimlilik değerlerinde aşırı boşluk suyu basıncı birikimi oluşmaktadır. Bu sonuç göstermektedir ki aşırı boşluk suyu basıncı oluşumunun birincil nedeni ağır yükler olmakla birlikte ikincil nedeni açı deniz sistemlerinde kazıkların geniş çaplı olmasıdır. Geniş çaplı kazık düşük geçirimlilik durumunda uzun bir boşluk suyu çıkış yoluna neden olarak adeta geçirimsiz bir duvar görevi görmektedir.

\section{KAYNAKLAR (REFERENCES)}

1. Taşan H.E., Akdağ C. T, Savidis S., "OffshoreRüzgar Enerjisi Temel Sistemleri-Tekil Kazık Temel Sisteminin Tekrarlı Yatay Yükler Altındaki Davranış1-", Zemin Mekaniği Temel Mühendisliği 13. Ulusal Kongresi, İstanbul Kültür Üniversitesi, İstanbul, 30 Eylül-1 Ekim 2010.

2. API-American Petroleum Institute, Recommended Practice for Planning, Designing and Constructing Fixed Offshore PlatformsWorking Stress Design. American Petroleum Institute, Washington, D.C., A.B.D., 2000

3. GL-Germanischer Lloyd, Rules and Guidelines, IV - Industrial Services, Part 2 - Guideline for the Certification of Offshore Wind Turbines, Germanischer Lloyd, Hamburg, Germany, 2005.

4. DNV-Det Norske Veritas, Offshore standard DNV-OS-J101, Design for Offshore Wind Turbine Structures, Det Norske Veritas, Norway, 2007.
5. Cox, W. R., Reese, L. C., Grubbs B. R., "Field Testing of Laterally Loaded Piles in Sand" Proceedings of the Sixth Offshore Technology Conference, OTC 2079, Houston, 459-472.1974.

6. Reese L. C., Cox W. R., Koop F. D., "Analysis of Laterally Loaded Piles in Sand.", Proceedings of the Sixth Offshore Technology Conference, OTC 2080, Houston, 2, 473-483. 1974.

7. Long, J. H. ve Vanneste, G., "Effects of cyclic lateral loads on piles in sand", Journal of Geotechnical Engineering, 120, 1, 225-244, 1994.

8. Bauer, E., "Calibration of Comprehensive Hypoplastic Model of Granular Materials" Soils and Foundations, 36, 1, 13-26, 1996.

9. Gudehus, G. "A Comprehensive Constitutive Equation for Granular Materials", Soils and Foundations, 36, 1, 1-12, 1996.

10. Kolymbas, D., Eine konstitutive Theorie für Böden und andere körnige Stoffe, Veröffentlichung des Institutes für Bodenmechanik und Felsmechanik der Universität Fridericana in Karlsruhe, Deutschland, 1988.

11. Herle, I., Hypoplastizität und Granulometrie einfacher Korngerüste, Veröffentlichung des Institutes für Bodenmechanik und Felsmechanik der Universität Fridericana in Karlsruhe, Deutschland, 1997.

12. von Wolffersdorff, P.-.A., "Hypoplastic Relation for Granular Materials with a Predefined Limit State Surface", Mechanics of CohesiveFrictional Materials, 1, 3, 251-271, 1996.

13. Niemunis, A. ve Herle, I., "Hypoplastic Model for Cohesionless Soils with Elastic Strain Range", Mechanics of Cohesion-Fractional Materials, 2, 4, 279-299, 1997.

14. Zienkiewicz, O. C., "The patch test for mixed formulations", International Journal for Numerical Methods in Engineering, 23, 10, 1873-1883, 1986.

15. Potts, D. M. ve Zdravković, L., Finite Element Analysis in Geotechnical Engineering, Theory, Thomas Telford,London, United Kingdom, 1999.

16. Taşan, H. E., Rackwitz F. ve Savidis.S, "Behaviour of Cyclic Laterally Loaded Large Diameter Monopiles in Saturated Sand", 7th European Conference on Numerical Methods in Geotechnical Engineering, NUMGE, Trondheim, Norway,889-894, 2-4 Haziran 2010.

17. Booker, J.R., "The Consolidation of a Finite Layer Subject to Surface Loading", International Journal of Soils and Structures, 10, 7, 10531065, 1974. 
